\title{
Determinants of bank profitability in a developing economy: empirical evidence from the China banking sector
}

\begin{abstract}
The Chinese banking sector has undergone noteworthy financial reforms, which significantly metamorphosed the banking system. This article seeks to examine the determinants of the profitability of the Chinese banking sector. The empirical analysis is confined to the four State Owned Commercial Banks (SOCBs) and the 12 Joint Stock Commercial Banks (JSCBs) during the postreform period of 2000ï 2007. The empirical findings of this study suggest that size, credit risk, and capitalization are positively related to the profitability of China banks, whereas liquidity, overhead costs, and network embeddedness have negative impacts. However, the impact of liquidity is not uniform across bank types. We find that the SOCBs with higher level of liquidity tend to be relatively more profitable, which could be vindicated by the significant amount of lending to the State Owned Enterprises. The impact of economic growth and inflation are always positive whether we examine the SOCB or the JSCB.
\end{abstract}

Keyword: Bank profitability; Multivariate regression analysis; China 